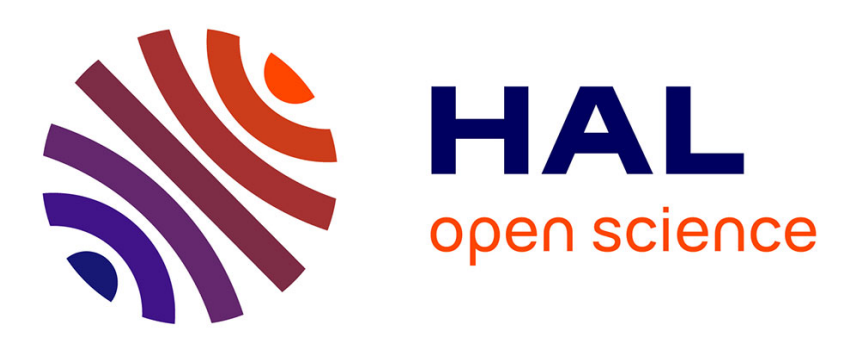

\title{
Effect of molybdenum and chromium contents on sliding wear of high-chromium white cast iron at high temperature
}

\author{
Karin Faria Pinho, Christine Boher, Cherlio Scandian
}

\section{- To cite this version:}

Karin Faria Pinho, Christine Boher, Cherlio Scandian. Effect of molybdenum and chromium contents on sliding wear of high-chromium white cast iron at high temperature. Lubrication Science, 2013, First International Brazilian Conference on Tribology (TriboBR 2010), 25 (2), pp.153-162. 10.1002/ls.1171 . hal-01687310

\section{HAL Id: hal-01687310 https://hal.science/hal-01687310}

Submitted on 25 Sep 2018

HAL is a multi-disciplinary open access archive for the deposit and dissemination of scientific research documents, whether they are published or not. The documents may come from teaching and research institutions in France or abroad, or from public or private research centers.
L'archive ouverte pluridisciplinaire HAL, est destinée au dépôt et à la diffusion de documents scientifiques de niveau recherche, publiés ou non, émanant des établissements d'enseignement et de recherche français ou étrangers, des laboratoires publics ou privés. 


\title{
Effect of molybdenum and chromium contents on sliding wear of high-chromium white cast iron at high temperature
}

\author{
Karin Faria Pinho ${ }^{1, *, \dagger}$, Christine Boher ${ }^{2}$ and Cherlio Scandian ${ }^{1}$ \\ ${ }^{1}$ Federal University of Espirito Santo (UFES), TRICORRMAT, Mechanical Engineering Department, 29075-910 Vitória, ES, \\ Brazil \\ ${ }^{2}$ Toulouse University, École des Mines d'Albi, ICA-Albi, F-81013 Albi Cedex, France
}

\begin{abstract}
High-chromium white cast irons are commonly used in applications requiring excellent abrasion resistance, as in the mining and mineral ore processing industry. Their excellent abrasion resistance is mainly due to their solidification microstructures. In this study, 15 experimental high-chromium white cast alloys containing different chromium and molybdenum contents and a ratio $\mathrm{Cr} / \mathrm{C}$ of 10 are examined. The wear experiments were carried out on a pin-on-disc tribometer at $700^{\circ} \mathrm{C}$. Microstructure has the most important role in dictating friction. It was observed that the wear loss was insignificant compared with that obtained at room temperature. The mean friction coefficient was also lower than that observed at room temperature sliding wear.
\end{abstract}

KEY WORDS: high-chromium white cast iron; friction; sliding wear; high temperature

\section{INTRODUCTION}

Tabrett et al. ${ }^{1}$ gave a range of chromium and carbon contents to define high-chromium white cast irons alloys. The respective contents of these elements are between 11 and $30 \mathrm{wt} \%$ for chromium and between 1.8 and $3.6 \mathrm{wt} \%$ for carbon. Composed of hard primary and/or eutectic carbides $\left(\mathrm{M}_{7} \mathrm{C}_{3}\right.$ type $)$ in a softer iron matrix (i.e. austenitic, martensitic, ferritic, pearlitic or bainitic), the microstructure of these alloys have been studied by several authors. ${ }^{1-5,12}$ By adding alloying elements, additional carbides such as $\mathrm{M}_{6} \mathrm{C}$ or $\mathrm{M}_{2} \mathrm{C}$ and $\mathrm{MC}$ are formed.

Generally, wear resistance depends on matrix microstructure, carbide type and characteristics (size, morphology, distribution and orientation ${ }^{6}$ ) as well as the volume fraction, and hardness of the alloys. ${ }^{7,8}$ It also depends on loading conditions, the features of the tribological environments and the type and size of the abrasive bodies.

\footnotetext{
*Correspondence to: Karin Pinho, Federal University of Espirito Santo (UFES), TRICORRMAT, Mechanical Engineering Department, 29075-910 Vitória, ES, Brazil.

†E-mail: karinfp@yahoo.fr
} 
Few studies have been related white to sliding wear of white cast irons at high temperature. ${ }^{9-11}$ Ikeda et al. ${ }^{9}$ have performed sliding wear experiments on a cast iron with a $\mathrm{Cr} / \mathrm{C}$ ratio of 5 . It is shown that by adding molybdenum, $\mathrm{M}_{2} \mathrm{C}$ carbides are formed, which contribute to enhancing hightemperature abrasion resistances. The addition of molybdenum, in quantities of more than $3 \mathrm{wt} \%$, to a high-chromium white cast iron leads to the formation of $\mathrm{M}_{2} \mathrm{C}$ or $\mathrm{M}_{6} \mathrm{C}$ carbides depending on the $\mathrm{Cr} / \mathrm{C}$ ratio. ${ }^{11,12}$ The contribution of a molybdenum content greater than $3 \%$ in improving the high temperature wear resistance have been previously examined. ${ }^{11}$

The general purpose of this study is to investigate the high-temperature sliding wear behaviour of 15 experimental white cast alloys containing different chromium (from 16 to $32 \mathrm{wt} \% \mathrm{Cr}$ ) and molybdenum (from Mo-free to $9 \mathrm{wt} \% \mathrm{Mo}$ ) contents and a $\mathrm{Cr} / \mathrm{C}$ ratio of 10 , which leads to the formation of $\mathrm{M}_{6} \mathrm{C}$ carbides instead of $\mathrm{M}_{2} \mathrm{C}$ carbides. ${ }^{12}$

\section{MATERIALS AND METHODS}

\section{Experimental procedure}

Friction tests were carried out on a pin-on-disc tribometer in dry conditions (Figure 1). The disc has a continuous rotating movement, and the linear velocity depends upon the radius of the wear track. The loading was applied using dead weights. The disc was heated by high frequency induction, and its surface temperature was controlled by an infrared pyrometer. The tribometer complete descriptions are reported in the literature. ${ }^{11,13}$

The disc was heated for $1 \mathrm{~h}$ at the test temperature (pre-oxidation). During pre-oxidation, the pin was kept at room temperature. After disc pre-oxidation, the pin was put on the disc, and the experiment was started. A strain gauge sensor continuously recorded the friction forces.

Pin geometry is given in Figure 2.

The pin height loss $(h)$ is calculated from the variation between the initial diameter of the contact surface $\left(D_{\mathrm{i}}\right)$ and its final diameter $\left(D_{\mathrm{f}}\right)$ (equation $\left.(1)\right)$. All diameters were measured by optical microscopy.

$$
h=\frac{\left(D_{\mathrm{f}}-D_{\mathrm{i}}\right)}{2}
$$
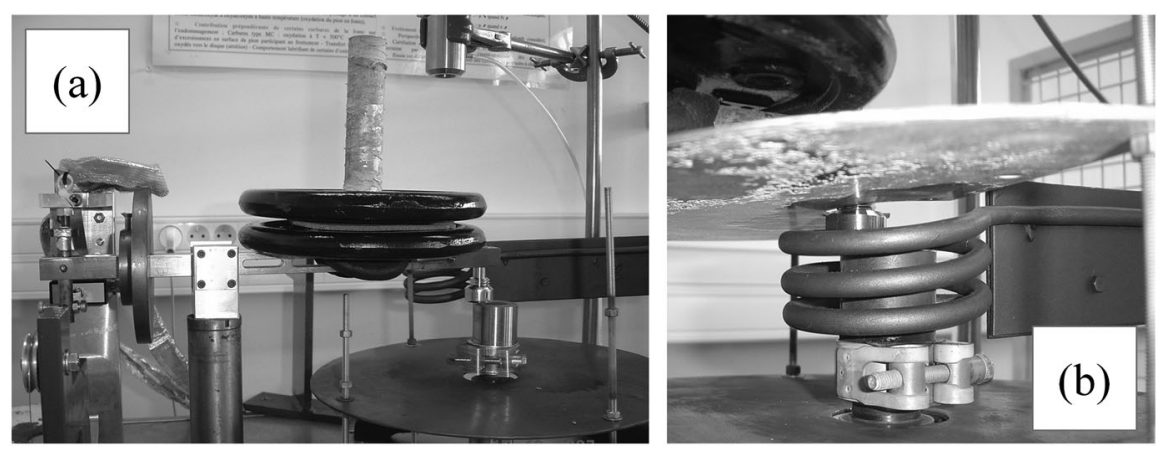

Figure 1. (a) General view of the pin-on-disc tribometer (b) and detail of the inductive heating system. 

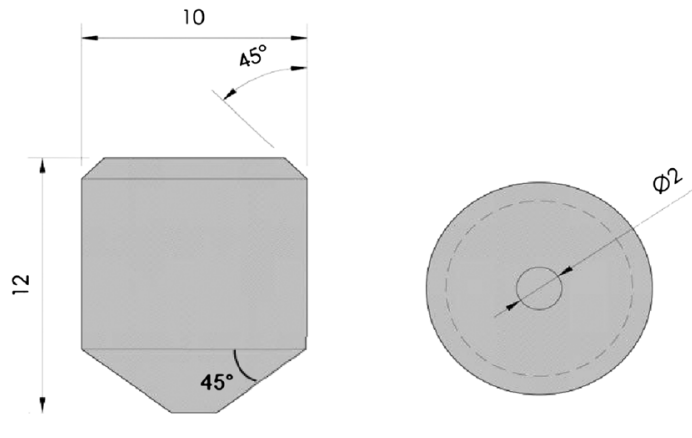

Figure 2. Pin geometry.

All friction experiments were performed under the same testing conditions, as summarised in Table I. Each friction test was carried out twice for repeatability considerations.

The worn surfaces were examined by optical and scanning electronic microscopy.

\section{Materials}

The disc material is a low-carbon SAE 1020. Pins are composed of white cast irons with different chromium and molybdenum contents. The chromium/carbon ratio is always 10 .

Four alloy groups have been studied: two groups are hypoeutectic alloys (16 and $24 \mathrm{wt} \% \mathrm{Cr}$ ); one group is a eutectic alloy $(28 \mathrm{wt} \% \mathrm{Cr}$ ) and the last one is a hypereutectic alloy ( $32 \mathrm{wt} \% \mathrm{Cr}$ ). For each group, four alloys with different Mo content (0, 3, 6 and $9 \mathrm{wt} \%)$ are investigated. The $28 \mathrm{wt} \% \mathrm{Cr}-6 \mathrm{wt} \% \mathrm{Mo}$ specimen has not been studied.

The microstructure of the Mo-free hypoeutectic alloys with $16 \mathrm{wt} \% \mathrm{Cr}$ consists of a dendritic-ferritic matrix $(\mathrm{Fe} \alpha)$ with interdendritic Maratray pearlite $\left(\alpha+\mathrm{M}_{7} \mathrm{C}_{3} \text { carbides }\right)^{2,11,12}$ surrounded by small interdendritic as well as eutectic $\mathrm{M}_{7} \mathrm{C}_{3}$ carbides.

According to the equilibrium phase diagram, the matrix should be austenitic and not ferritic. This phase modification is relevant to the die casting cooling process. ${ }^{11,12}$

With the Mo-free and $24 \mathrm{wt} \% \mathrm{Cr}$, the microstructure is still dendritic but composed of $\alpha / \alpha^{\prime}$ (ferritic and martensitic). ${ }^{11,12}$

For the Mo-free and $28 \mathrm{wt} \% \mathrm{Cr}$ (eutectic alloys group), the microstructure consists of mixed strips of $\alpha$ and $\mathrm{M}_{7} \mathrm{C}_{3}$ carbides. The carbide size is about $10-20 \mu \mathrm{m} .^{11,12}$

For the eutectic alloys group, the large primary carbides capture a considerable amount of carbon content. The matrix is ferritic due to the slow cooling rate of the casting process.

The Mo addition in hypoeutectic alloys inhibits the austenitic transformation into pearlite and facilitates the formation of a martensite microstructure, thus increasing the hardenability of the alloy. ${ }^{1,2}$ For hypoeutectic alloys, three different phases are present in the matrix dendrites (ferrite $\alpha /$ martensite

Table I. Frictional experimental conditions.

\begin{tabular}{lccc}
\hline Sliding speed & Normal load & Test duration & Temperature \\
\hline $0.1 \mathrm{~m} \mathrm{~s}^{-1}$ & $20 \mathrm{~N}$ & $1800 \mathrm{~s}$ & $700^{\circ} \mathrm{C}$ \\
\hline
\end{tabular}


$\alpha^{\prime}$ /austenite $\gamma$ ). The amount of interdendritic $\mathrm{M}_{7} \mathrm{C}_{3}$ carbides increases with dendrite size enhancements. New eutectic carbides $\left(\mathrm{M}_{6} \mathrm{C}\right.$ carbides) coarsened because molybdenum is a carburising element. ${ }^{11,12}$

The Mo alters the $\mathrm{Cr}-\mathrm{C}$ equilibrium and modifies the phase diagram domains in eutectic and hypereutectic alloys, which strongly influences the alloy microstructure: ${ }^{11}$

- The as-known eutectic alloy $(28 \mathrm{wt} \% \mathrm{Cr})$ becomes a hypereutectic type alloy with primary $\mathrm{M}_{7} \mathrm{C}_{3}$ carbides, $\mathrm{M}_{6} \mathrm{C}$ carbides and a ferritic matrix.

- The as-known hypereutectic alloy $\left(32 \mathrm{wt} \% \mathrm{Cr}\right.$ ) keeps the primary $\mathrm{M}_{7} \mathrm{C}_{3}$ carbides with a ferritic matrix microstructure and develops $\mathrm{M}_{6} \mathrm{C}$ carbides.

The complete characterisation of these alloys had been determined in a previous study. ${ }^{12}$ Their microstructural phases and type of carbides are illustrated in Figure 3.

The volume fraction of the matrix and carbides are determined by image analysis. ${ }^{12}$ The volume fraction of the matrix decreases as the content of the alloying elements increases, since $\mathrm{M}_{7} \mathrm{C}_{3}$ and $\mathrm{M}_{6} \mathrm{C}$ eutectic carbides are formed, as well as $\mathrm{M}_{7} \mathrm{C}_{3}$ primary carbides (Figure $4 \mathrm{a}$ ).

The average area of $\mathrm{M}_{7} \mathrm{C}_{3}$ carbides is strongly influenced by the Mo content, reaching a maximum value for the $6 \mathrm{wt} \%$ Mo alloys (Figure 4b). The average areas of $\mathrm{M}_{7} \mathrm{C}_{3}$ carbides for hypereutectic alloys $(32 \mathrm{wt} \% \mathrm{Cr}$ ) have been discarded due to the presence of primary carbides, that exhibit much higher dimensions. ${ }^{12}$

\section{RESULTS AND DISCUSSION}

\section{Friction results}

Friction results are shown in Table II.

For Mo-free alloys, the mean value of the friction coefficient is practically constant, except for the hypoeutectic Mo-free-24 wt\% Cr alloy that shows a lower value. Eutectic and hypereutectic alloys display slightly higher values. For multiphased matrix alloys (hypoeutectic alloys with any molybdenum content, except the $24 \mathrm{wt} \% \mathrm{Cr}-9 \mathrm{wt} \%$ Mo alloy), friction coefficient depends on molybdenum content.

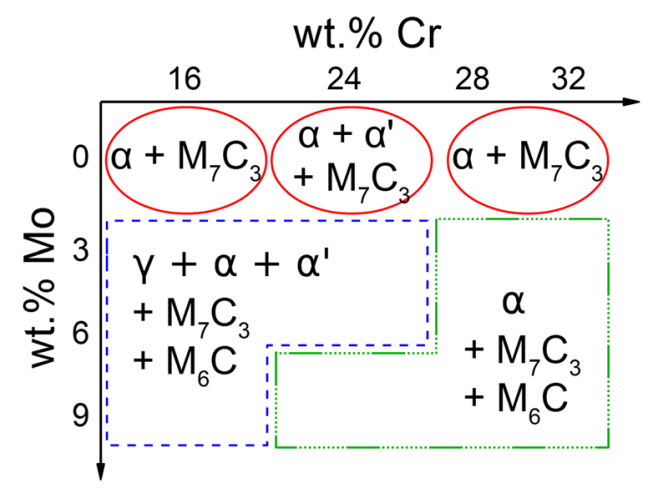

Figure 3. Phases of the different experimental white cast alloys as a function of chromium and molybdenum contents (wt\%). 


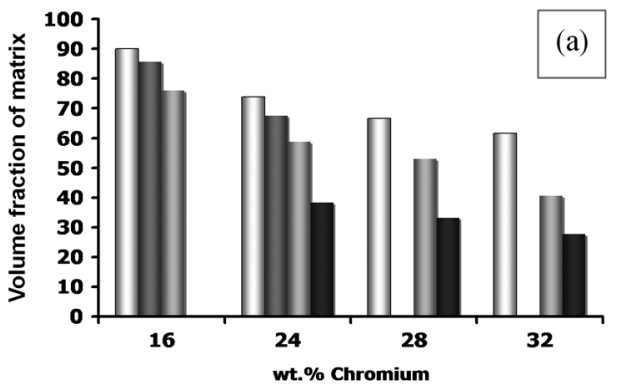

足 $0 \%$ Mo $3 \%$ Mo $6 \%$ Mo $9 \%$ Mo

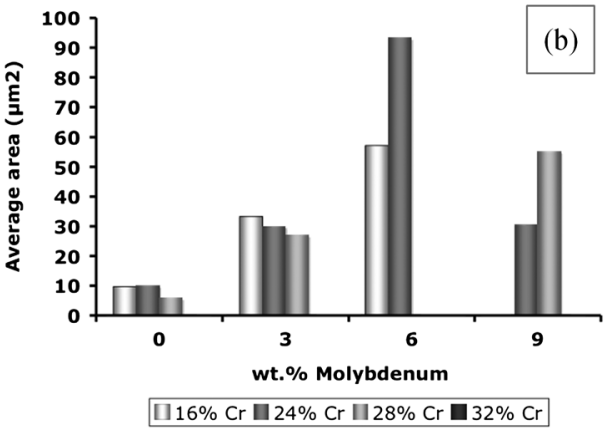

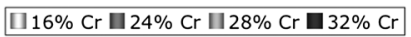

Figure 4. (a) Volume fraction of matrix (\%) as a function of chromium and molybdenum contents (wt $\%$ ) and (b) average area of $\mathrm{M}_{7} \mathrm{C}_{3}$ carbides $\left(\mu \mathrm{m}^{2}\right)$.

Table II. Mean friction coefficient values after sliding wear at $700^{\circ} \mathrm{C}$.

\begin{tabular}{lcccc}
\hline \multicolumn{5}{c}{ wt\% Cr } \\
\hline wt\% Mo & 16 & 24 & 28 & 32 \\
\hline 0 & 0.5 & 0.2 & 0.45 & 0.45 \\
3 & 0.1 & 0.2 & 0.5 & 0.5 \\
6 & 0.5 & 0.5 & - & 0.55 \\
9 & 0.35 & 0.5 & 0.55 & 0.55 \\
\hline
\end{tabular}

Previous studies ${ }^{13-15}$ obtained friction results around 0.5 for similar materials and test conditions. Figure 5 illustrates the general aspect of the evolution of friction coefficient versus test duration. At this point, it is important to remark that the mean value of the friction coefficient obtained at high temperature is lower than that observed at room temperature. ${ }^{11}$
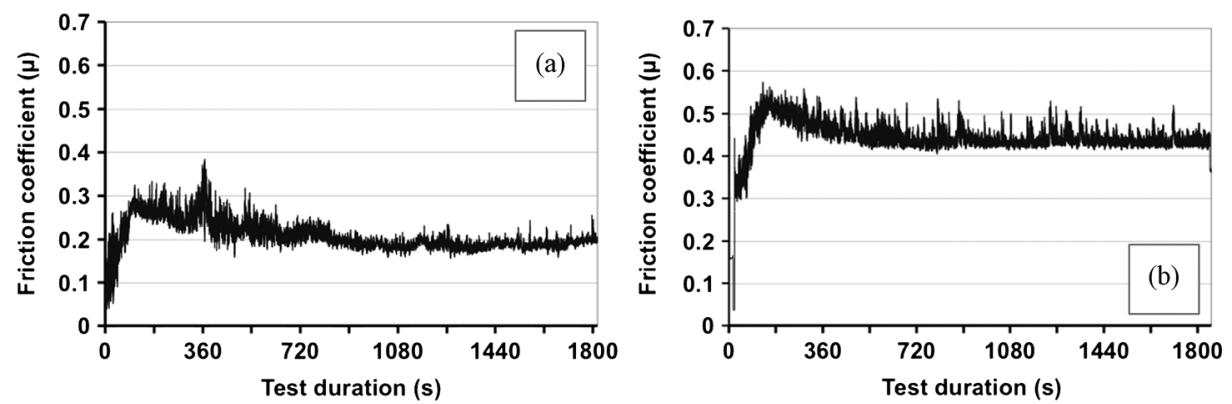

Figure 5. Friction coefficient versus test duration for (a) Mo-free alloy with martensitic matrix and (b) hypoeutectic alloy $16 \mathrm{wt} \% \mathrm{Cr}-6 \mathrm{wt} \%$ Mo. 


\section{Role of microstructure on friction}

Scanning electronic microscopy examinations of worn surfaces of the pins reveal that there is a preferential transference of oxides from the disc and, then, adhesion to the matrix of the pin, specifically on the $\alpha-\mathrm{Fe}$, due to its ductile characteristic. Occasionally, the oxides transferred are found attached to the $\mathrm{M}_{7} \mathrm{C}_{3}$ carbides, but never to the $\mathrm{M}_{6} \mathrm{C}$ carbides of the pin. Moreover, microcracks are always clearly observed with $\mathrm{M}_{7} \mathrm{C}_{3}$ carbides and rarely with $\mathrm{M}_{6} \mathrm{C}$ (Figure 6). This is a behaviour that seems to rule the coefficient friction values.

An increase in the volume fraction of the matrix or $\mathrm{M}_{6} \mathrm{C}$ carbides of hypoeutectic alloys tends to reduce the friction coefficient probably due to the following: (i) the adhesion of oxides transferred from the disc in the matrix forms an oxide film that avoids the contact between surfaces; (ii) the physical characteristics of $\mathrm{M}_{6} \mathrm{C}$ carbide - because ceramic-ceramic contacts present lower friction coefficient than in metals sliding and present a great hardness combined to an excellent wear resistance, this type of carbide exhibits practically no fracture. In opposition, microcracking of $\mathrm{M}_{7} \mathrm{C}_{3}$ carbides leads to an increased friction because the occurrence of fracture provides an additional mechanism for the dissipation of energy at the sliding contact. ${ }^{16}$

The relationship between the mean friction coefficient and the volume fraction of the matrix and carbides in hypoeutectic alloys can be observed in Figure 7. For the same chromium content alloys, the higher is the volume fraction of the matrix — and then, the higher the area covered with oxides - in contrast with the volume fraction of $\mathrm{M}_{7} \mathrm{C}_{3}$ carbides, the lower is the mean value of the friction.

Another remarkable observation is that, besides the volume fraction of matrix and carbides, the carbide size and the distribution of phases in microstructure seems to influence considerably the friction coefficient results. An evidence of that can be pointed out in a comparison between the friction results of the $24 \mathrm{wt} \% \mathrm{Cr}-3 \mathrm{wt} \% \mathrm{Mo}$ and $16 \mathrm{wt} \% \mathrm{Cr}-6 \mathrm{wt} \%$ Mo alloys considering their microstructures characteristics (Table III).

Despite the higher volume fraction of matrix and $\mathrm{M}_{6} \mathrm{C}$ carbides and the lower volume fraction of $\mathrm{M}_{7} \mathrm{C}_{3}$ carbides of the $16 \mathrm{wt} \% \mathrm{Cr}-6 \mathrm{wt} \%$ Mo alloy, it has a greater friction coefficient. This fact is probably due to the distinct distribution of phases in its microstructure, which forms a more discontinuous
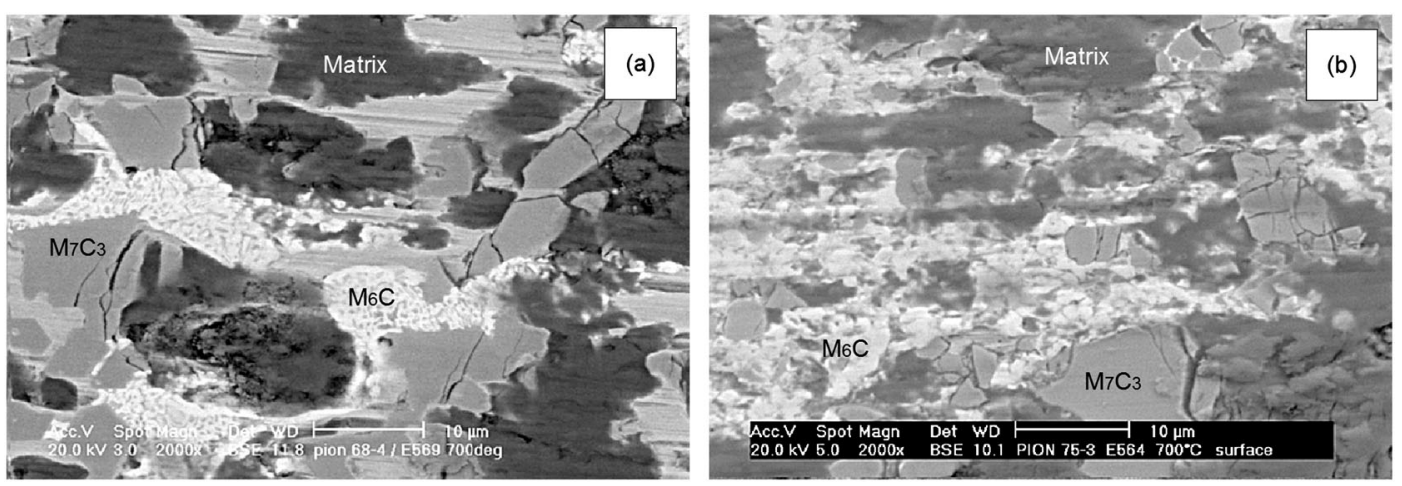

Figure 6. Scanning electronic microscopy observations of microcracks in $\mathrm{M}_{7} \mathrm{C}_{3}$ carbides, intact $\mathrm{M}_{6} \mathrm{C}$ carbides and oxides from the disc attached to the matrix in (a) a hypoeutectic alloy ( $24 \mathrm{wt} \% \mathrm{Cr}-6 \mathrm{wt} \% \mathrm{Mo}$ ) and (b) a hypereutectic alloy ( $32 \mathrm{wt} \% \mathrm{Cr}-9 \mathrm{wt} \% \mathrm{Mo})$. The darker areas correspond to the matrix covered by oxides; the lighter areas, to the $\mathrm{M}_{6} \mathrm{C}$ carbides and the medium grey areas, to the $\mathrm{M}_{7} \mathrm{C}_{3}$. 

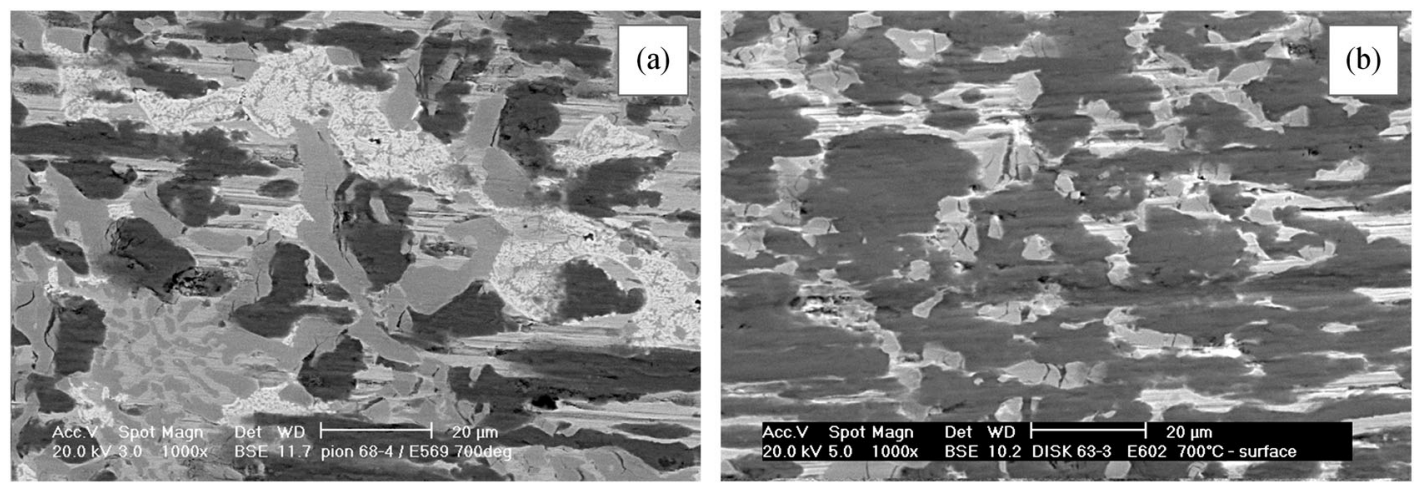

Figure 7. Microstructure of the hypoeutectic alloys with the same chromium content: (a) $24 \mathrm{wt} \% \mathrm{Cr}-6 \mathrm{wt} \% \mathrm{Mo}$ and (b) $24 \mathrm{wt} \% \mathrm{Cr}-3 \mathrm{wt} \% \mathrm{Mo}$. Alloy (b) presents higher volume fraction of matrix and lower volume fraction of $\mathrm{M}_{7} \mathrm{C}_{3}$ carbides. The darker areas correspond to the matrix covered by oxides; the lighter areas, to the $\mathrm{M}_{6} \mathrm{C}$ carbides and the medium grey areas, to the $\mathrm{M}_{7} \mathrm{C}_{3}$.

Table III. Characteristics of two hypo-eutectic alloys with different chromium contents as a function of volume fraction of phases, hardness and friction coefficient. ${ }^{12}$

\begin{tabular}{lcc}
\hline & $16 \mathrm{wt} \% \mathrm{Cr}-6 \mathrm{wt} \% \mathrm{Mo}$ & $24 \mathrm{wt} \% \mathrm{Cr}-3 \mathrm{wt} \% \mathrm{Mo}$ \\
\hline Vickers hardness $\left(\mathrm{HV}_{10}\right)$ & 557 & 583 \\
Volume fraction of matrix $(\%)$ & 75.9 & 67.6 \\
Volume fraction of $\mathrm{M}_{7} \mathrm{C}_{3}$ carbides $(\%)$ & 14.5 & 27.1 \\
Volume fraction of $\mathrm{M}_{6} \mathrm{C}$ carbides $(\%)$ & 9.6 & 5.3 \\
Friction coefficient & 0.5 & 0.2 \\
\hline
\end{tabular}

oxide film — and, then, a less protective oxide layer — than that observed in the $24 \mathrm{wt} \% \mathrm{Cr}-3 \mathrm{wt} \% \mathrm{Mo}$ alloy (Figure 8). Darker areas correspond to matrix covered by oxides; lighter areas, to $\mathrm{M}_{6} \mathrm{C}$ carbides and medium grey areas, to $\mathrm{M}_{7} \mathrm{C}_{3}$.
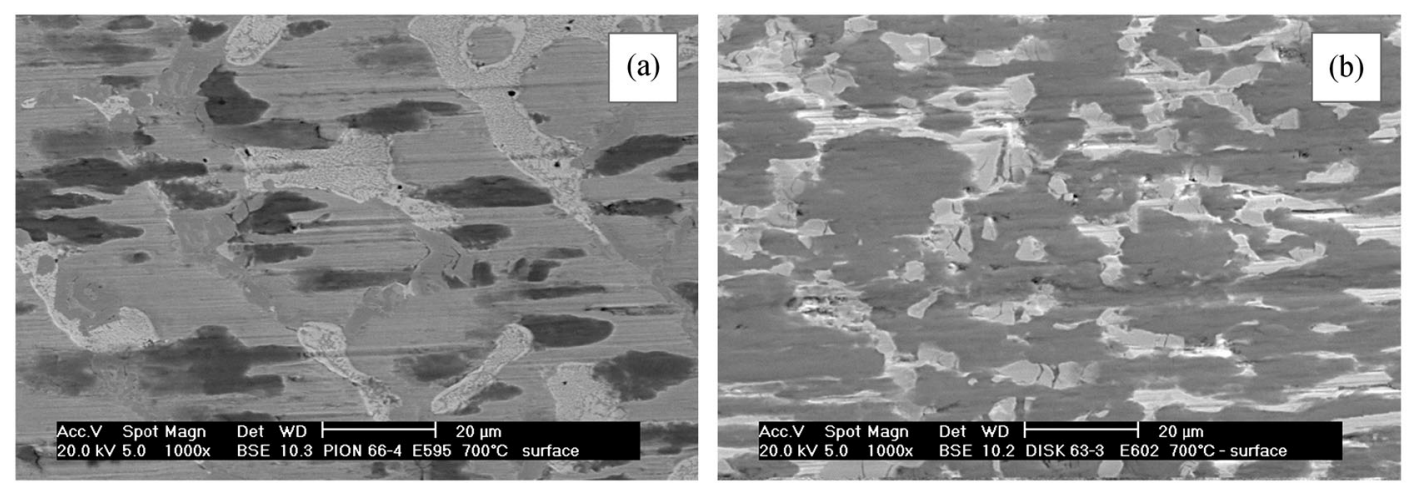

Figure 8. Distribution of phases in hypoeutectic alloys: (a) $16 \mathrm{wt} \% \mathrm{Cr}-6 \mathrm{wt} \%$ Mo and (b) $24 \mathrm{wt} \% \mathrm{Cr}-3 \mathrm{wt} \% \mathrm{Mo}$. The oxide film is more discontinuous in alloy (b) and then forms a less protective layer. 

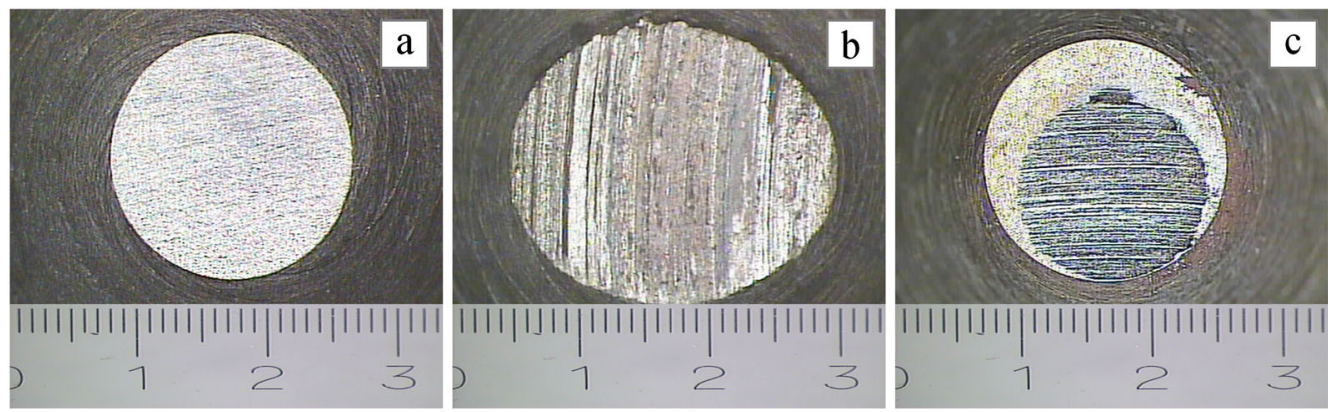

Figure 9. Eutectic alloy ( $28 \mathrm{wt} \% \mathrm{Cr}-3 \mathrm{wt} \% \mathrm{Mo})$ : (a) before the test; (b) after the test at room temperature and (c) after the test at $700^{\circ} \mathrm{C}$.

Another relevant consideration in the friction behaviour of the former alloy is that the average area of $\mathrm{M}_{7} \mathrm{C}_{3}$ carbides is about two times higher (Figure $4 \mathrm{~b}$ ). Thus, microcracking of $\mathrm{M}_{7} \mathrm{C}_{3}$ carbides seems to be more significant in dictating friction particularly when their average area is higher than $50 \mu^{2}$, as in the eutectic and hypereutectic alloys, as well as $6 \mathrm{wt} \%$ Mo alloys, which display slightly higher values of mean friction coefficient.

For Mo-free alloys, the mean value of the friction coefficient is practically constant except for the hypoeutectic Mo-free-24 wt\% Cr alloy that shows a lower value probably due to its duplex ferriticmartensitic matrix in place of a ferritic single-phased one. The martensitic phase shows lower plasticity that could explain the lower friction coefficient, since it provides mechanical support for the oxide film. ${ }^{17}$

\section{Wear results}

For the tested conditions and alloys, the wear loss is insignificant no matter the composition or hardness of the alloy (total pin height loss between 0 and $70 \mu \mathrm{m}$ ). Once the oxides are transferred from the oxide layer formed during pre-oxidation of the disc to the matrix of the pin surface, the contact of bulk materials are prevented and little or none wear occurs.

Many previous studies ${ }^{13-15,18,19}$ tested similar materials and conditions. Therefore, the results emphasise mainly the wear mechanisms involved in sliding wear. Barrau et al. ${ }^{14}$ tested a martensitic tool steel (AISI H11) against AISI 1018 at various tribological conditions, and for a similar experimental condition tested in this work $\left(700^{\circ} \mathrm{C}, 20 \mathrm{~N}\right)$, the total pin height loss was $55 \mu \mathrm{m}$.

Moreover, lower wear loss is expected in sliding at high temperatures due to surface oxidation, since a substantial oxide film can suppress the plasticity-dominated mechanisms by reducing the shear strength of the interface. ${ }^{17} \mathrm{~A}$ comparison can be made between the worn surfaces of the present study and the previous one at room temperature (Figure 9), in which the pin height loss $(h)$ can be higher than $0.8 \mathrm{~mm} .{ }^{11}$

\section{CONCLUSIONS}

For the tested alloys, the oxides are always observed attached to the matrix and occasionally to the $\mathrm{M}_{7} \mathrm{C}_{3}$ carbides, but never to the $\mathrm{M}_{6} \mathrm{C}$ carbides. Besides that, microcracks are always observed with eutectic or primary $\mathrm{M}_{7} \mathrm{C}_{3}$ carbides, but rarely with $\mathrm{M}_{6} \mathrm{C}$. 
The attached oxides to the matrix avoid the contact between the bulk materials and, therefore, reduce the wear loss and the friction coefficient. The higher the volume fraction of the matrix — then, the greater the area covered by oxides - the higher the tendency to reduce friction.

Microcracking of $\mathrm{M}_{7} \mathrm{C}_{3}$ carbides seems to contribute greatly to friction results due to dissipation of energy at sliding contact. As the volume fraction of this type of carbides and, specially, its average area increase, the mean friction coefficient values tend to be higher. In opposition, the presence of $\mathrm{M}_{6} \mathrm{C}$ carbides tends to reduce friction.

Frictional behaviour seems to be controlled by the three phenomena related above: formation of an oxide layer, volume fraction and size of $\mathrm{M}_{7} \mathrm{C}_{3}$ carbides and presence of $\mathrm{M}_{6} \mathrm{C}$ carbides. Therefore, friction results are due to the competition between these phenomena and cannot be predicted by the analysis of each one individually.

The friction coefficient values obtained at high temperature are lower than that observed at room temperature sliding wear.

The wear results highlight that, for the tested conditions and alloys, the wear loss tends towards zero in contrast with the room temperature wear results.

\section{ACKNOWLEDGEMENT}

The authors would like to acknowledge the contributions of DSc. Pedro Carneiro.

\section{REFERENCES}

1. Tabrett CP, Sare IR, Ghomaschil MR. Microstructure-property relationships in high chromium white iron alloys. International Materials Reviews 1996; 41: 59-80.

2. Maratray F, Usseglio-Nanot R. Facteur Affectant la Structure des Fontes Blaches au Chrome et au Molybdène (1st edn), Climax Molybdenum, 1970: 5-32

3. Powell LF, Heard LS. Misinterpretation of microstructure in wear resistant alloy white irons. Proceedings of 34th Annual Conference of Australian Institute of Materials, Queensland, Australia, 1981: 58-62.

4. De Mello JDB, Durrand-Charre M, Hamar-Thibault MS. Solidification and solid state transformations during cooling of chromium-molybdenum white cast irons. Metallurgical and Materials Transactions A 1983; 14 A: 1793-1801.

5. Dogan ON, Hawk G, Laird II G. Solidification structure and abrasion resistance of high chromium white irons. Metallurgical and Materials Transactions A 1997; 28A: 1315-1328.

6. Dogan ON, Hawk JA. Effect of carbide orientation on abrasion of high Cr white cast iron. Wear 1995; 189: $136-142$.

7. Zum Gahr KH, Eldis GT. Abrasive wear of white cast irons. Wear 1980; 64: 175-194.

8. Zum Gahr KH. Wear by hard particles. Tribology International 1998; 31: 587-596.

9. Ikeda M, Umeda T, Tong CP, Suzuki T, Niwa N, Kato O. Effect of molybdenum addition on solidification structure, mechanical properties and wear resistivity of high chromium cast irons. ISIJ International 1992; 32: $1157-1162$.

10. Milan JCG, Carvalho MA, Xavier RR, Franco SD, De Mello JDB. Effect of temperature, normal load and pre-oxidation on the sliding wear of multi-component ferrous alloys. Wear 2005; 259: 412-423.

11. Scandian C, Boher C, De Mello JDB, Rézaï-Aria F. Effect of molybdenum and chromium contents in sliding wear of high-chromium white cast iron: the relationship between microstructure and wear. Wear 2009; 267: 401-408.

12. Carvalho SM, Macêdo MCS, De Mello JDB, Scandian C. The influence of $\mathrm{Cr}$ and Mo on the microstructure of the high chromium white cast iron with $\mathrm{Cr} / \mathrm{C}=10$. Materials Characterization, to be published.

13. Barrau O, Boher C, Gras R, Rézaï-Aria F. Analysis of the friction and wear behaviour of hot work tool steel for forging. Wear 2003; 255: 1444-1454.

14. Barrau O, Boher C, Gras R, Rézaï-Aria F. Wear mechanisms and wear rate in a high temperature dry friction of AISI H11 tool steel: influence of debris circulation. Wear 2007; 263: 160-168. 
15. Joos O, Boher C, Vergne C, Gaspard C, Nylen T, Rézaï-Aria F. Assessment of oxide scales influence on wear damage of HSM work rolls. Wear 2007; 263: 198-206.

16. Bhushan B. Introduction to Tribology (1st edn), John Wiley \& Sons: New York, 2002.

17. Hutchings IM. Tribology: Friction and Wear of Engineering Materials, Edward Arnold: London, 1992.

18. Vergne C, Boher C, Levaillant C, Gras R. Analysis of the friction and wear behavior of hot work tool scale: application to the hot rolling process. Wear 2001; 250: 322-333.

19. Vergne C, Boher C, Gras R, Levaillant C. Influence of oxides on friction in hot rolling: experimental investigations and tribological modeling. Wear 2006; 260: 957-975. 